Покровська Н.М.

Національний технічний університет України «КПI»

\title{
ЕКОНОМІЧНА СУТНІСТЬ ПОНЯТТЯ «ІНТЕНСИФІКАЦІЯ ВИРОБНИЦТВА» \author{
ПРОИЗВОДСТВА»
} \\ ЭКОНОМИЧЕСКАЯ СУЩНОСТЬ ПОНЯТИЯ «ИНТЕНСИФИКАЦИЯ
}

\section{ECONOMIC ESSENCE OF THE CONCEPT "THE INTENSIFICATION OF PRODUCTION"}

У статті досліджено теоретико-методологічні аспекти економічної сутності інтенсифікації виробництва, та проаналізовано наукові погляди представників різних економічних шкіл на сутність иієї економічної категорії.Зазначено, щзо на сьогодні існує різноманіття точок зору на сутність ідентифікації, що в свою чергу свідчить про незавершеність прочесу формування теорії інтенсифікації виробництва. Систематизовано наукові уявлення з позицій теорії відтворення, «затратного», "результативного», «технічного» та «комплексного» підходів. Показано, щуо існуючі наукові погляди про визначення сутності інтенсифікачії виробництва об'єднує те, щзо відправною точкою у кожного з них є розгляд виробництва як процесу, або як системи, або як процесу $і$ системи одночасно. На основі проведеного аналізу уточнено сутність інтенсифікації виробництва. Запропоновано інтенсифікацію виробництва розглядати як системний процес та запропоновано коротке та розгорнуте визначення інтенсифікації виробництва як системного процесу.

Ключові слова: виробництво, інтенсифікація виробництва, система, процес, системний процес

В статье исследовань теоретико-методологические аспекты экономической сущности интенсификации производства и проанализированы научные взгляды представителей разных экономических школ на сущность интенсификачии производства. Показано, что в настоящее время сущчествует разнообразие точек зрения на сущцость интенсификации, что в сою очередь свидетельствует о незавершенности процесса формирования теории интенсификации производства. Систематизированы научные представления о сущуности интенсификации производства $c$ позиций теории воспроизводства, «затратного», «результативного», «технического» и «комплексного» подходов. Показано, что существующие научные взгляды на определение сущности интенсификачии производства объединяет то, что отправной точкой у каждого из них есть рассмотрение производства как процесса, или как системы, или как процесса и системы одновременно. На основе проведенного анализа уточнена сущность интенсификации производства. Предложено интенсификацию производства рассматривать как системный процесс и предложено короткое и развернутое определение интенсификации производства как системного процесса.

Ключевые слова: производство, интенсификация производства, система, процесс, системный процесс

The article deals with some theoretical and methodological aspects of the economic substance of production intensification. The existing scientific views of different economic schools on the nature of production intensification are analysed. It is shown that at present there is a diversity of views on the nature of identity which in turn indicates an incomplete process of the 
intensification theory formation. Scientific understanding of the production intensification nature from the standpoint of the reproduction theory, "cost-effective", "effective", "technical", and "comprehensive" approaches is systematized. It is also shown that the existing scientific views on the definition of the production intensification essence in common reduce to the starting point for each of them to consider manufacturing as a process, or a system, or a process and a system at one time. The production intensification essence is made here more exact based on the given analysis. It is proposed to consider production intensification as a system process and is offered a brief and detailed definition of production intensification as such system process. Keywords: production, production intensification, system, process, system process.

Вступ.Рух України шляхом євроінтеграції потребує створення конкурентоспроможної національної економіки як необхідної умови економічного зростання [1].

Нестабільність на зовнішньоекономічному просторі, дія кризових явищ, зміни в кон'юнктурі ринку та, як наслідок, посилення дії впливу факторів макроекономічного середовища ускладнюють процес функціонування вітчизняних підприємств, що в подальшому впливає на кінцевий результат їх діяльності.

Однією з передумов успішного виведення вітчизняної економіки на траєкторію сталого розвитку слід вважати інтенсифікацію виробництва.

Правильний вибір пріоритетних напрямів інтенсифікації виробництва неможливий без розуміннясутності інтенсифікації виробництва,що обумовлює необхідність подальшого розвитку теоретичних та методологічних засад цього поняття.

Різні аспекти сутності інтенсифікації виробництва досліджували вітчизняні та зарубіжні вчені-економісти, такі як:О.ІАмоша, С.В. Мочерний, В.С. Горбачов, О.П. Гурченков, Н.А. Агаркова, В.В. Шарко, Т.С. Яровенко, М.В. Туликова, Ю.А. Козюпа, Ф.А. Важинський, Л.С. Ножак, Ю.Б. Шульган, М.С. Вітков, С.В. Степаненко, Д. Другманд, Н. Хавеландж та інші.

Незважаючи на досить широку палітру наукових досліджень даного питання у літературі, окремі його сторони потребують більш поглибленого вивчення.

Постановка завдання.Мета статті полягає в узагальненні теоретикометодологічних підходів до визначення сутності інтенсифікації виробництва та подальшого розвитку даної економічної категорії з урахуванням методології та практики управління процесами інтенсифікації промислового виробництва.

Методологія. Дослідження проводилося із застосуванням методів теоретичного узагальнення та порівняння, аналізу і синтезу. Зазначені методи дали можливість систематизувати наукові погляди на сутність інтенсифікації виробництва, забезпечили проведення змістовного аналізу наукових підходів до визначення та уточнення на їх основі сутності інтенсифікації виробництва.

Результати дослідження. Сьогодні існує різноманіття точок зору на сутність ідентифікації, що в свою чергу свідчить про те, що процес формування теорії інтенсифікації виробництва ще не завершено. 
У витоків наукового вивчення процесу інтенсифікації виробництва стояли класики політичної економії: Д.Рікардо, А.Сміт, К. Маркс та інші вченіекономісти. Їхні наукові здобутки є базовими для розуміння сутності цього питання.

Аналізуючи трактування сутності поняття «інтенсифікація виробництва», яке наводять вітчизняні та зарубіжні вчені, виявилося, що більшість 3 них виходять 3 відправного визначення цього терміну, яке наводив К. Маркс, а саме: «...В економічному значенні під інтенсивною культурою ми розуміємо не що інше, як концентрацію капіталу на одній i тій самій земельній площі, замість розподілу його між земельними ділянками, які лежать одна біля другої...» [2, с.209]. Ці положення стосуються інтенсифікації перш за все землеробства, однак, їх можна застосувати й до інтенсифікації виробництва в промисловості. На думку К.Маркса, не доцільно вважати виробництво інтенсивним, якщо капітал направляється на його розширення, тобто на будівництво нових одиниць (структурних підрозділів, будівель тощо).

Така ж думка щодо розвитку виробництва висловлена К. Марксом і в другому томі «Капіталу», а саме: «...через певні проміжки часу відбувається відтворення, і до того ж - коли розглядати його з суспільної точки зору, відтворення в розширеному масштабі: розширеному екстенсивно, коли розширюється лише поле виробництва; розширеному інтенсивно, коли застосовуються більш ефективні засоби виробництва» [3, с.178]. Це є класичне визначення особливостей двох шляхів розвитку виробництва, двох шляхів розширеного відтворення - інтенсивного та екстенсивного, на яких базувалися дослідження з інтенсифікації виробництва вчених багатьох країн.

Необхідно зазначити, що понятійний апарат інтенсифікації виробництва бере початок із визначення самого поняття «інтенсифікація».

Якщо звернутися до словникового визначення терміну «інтенсифікація», то у дослівному перекладі інтенсифікація (від латинського intensio напруження, посилення i facio - роблю) означає посилення, збільшення напруженості, продуктивності, дієвості. Таким чином, інтенсифікація $\epsilon$ напруженістю процесу, яка характеризується мірою віддачі кожного 3 використовуваних факторів, ресурсів, тобто $є$ якісною характеристикою, що виражає високу міру, ступінь сили, напруженості, насиченості якогось прояву чи процесу [4].У авторів [5]знаходимо, що інтенсифікація - це підвищення інтенсивності виробництва шляхом більш повного використання кожної одиниці ресурсного потенціалу; досягається за рахунок зростання продуктивності праці, кращого використання матеріалів, підвищення віддачі основних фондів.

Відповідно до енциклопедичного визначення - сутність інтенсифікації виробництва розглядається як процес суспільного виробництва, що базується на застосуванні найефективніших засобів і предметів праці, кваліфікованої робочої сили, передових форм і методів організації праці, зростаючої інформованості про найновіші досягнення науково-технічного прогресу тощо. Інтенсифікація виробництва суттєво відрізняється від екстенсивного розвитку суспільного виробництва, що базується на кількісному зростанні засобів 
виробництва і має витратний характер. На відміну від екстенсивного інтенсивний процес суспільного виробництва має антивитратну спрямованість, оскільки супроводжується зменшенням витрат живої та уречевленої праці на одиницю продукції [6].

В економічній літературі інтенсифікація виробництва досить часто розглядається як частина теорії відтворення. Під відтворенням розуміють процес виробництва в його безперервності, у постійному відновленні, повторенні. При цьому безперервність виробничого процесу розглядається не 3 точки зору технології, а в економічному значенні.

У дослідженні [7] зазначено, що частина авторів розуміють під інтенсифікацією статичну якісну характеристику суспільного відтворення, яка відображає досягнутий рівень продуктивних сил науково-технічного прогресу і кваліфікації сукупного робітника, або якісні зрушення у використанні ресурсів виробництва, які відбуваються в межах виробничого циклу. Інші дослідники вважають що інтенсифікація - це динамічний процес якісного вдосконалення виробничих сил і виробничих відносин, особливий спосіб відтворення та використання наявного виробничого потенціалу.

В свою чергу вчені [7] вважають, що процес інтенсифікації виробництва являє собою діалектичну єдність і взаємно доповнення економічних і технікотехнологічних параметрів, які визначають інтенсивність чи екстенсивність розширеного відтворення. На думку авторів із техніко-технологічної точки зору інтенсивним доцільно вважати такий процес розширеного відтворення, при якому зростає наукоємність виробництва; техніко-технологічна структура підприємства удосконалюється та поліпшується внаслідок практичного використання більш ефективних, технічно вдосконалених засобів виробництва на основі досягнень науково-технічного прогресу, більш кваліфікованих кадрів, передових методів організації праці; нових матеріалів, при цьому якісний рівень виробничо-маркетингової системи та ефективність використання ресурсів підвищуються, зростає конкурентоспроможність продукції, частка ринків збуту, що збільшує результати від реалізації продукції. Екстенсивний процес розширеного відтворення характеризується розширенням і збільшенням ресурсів, які залучаються у виробництво без якісних удосконалень виробничомаркетингової системи.

Як стверджують В.С. Горбачов, О.П. Гурченков та Н.А. Агаркова зустрічаються й такі трактування інтенсифікації виробництва, при яких автори дотримуються «затратної» та «результативної» концепції[8, 9]. Прихильники «затратної» концепції розглядають інтенсифікацію виробництва як рух витрат праці, виражених у вартісній формі Таким чином, має місце концентрація капіталу 3 метою нарощення обсягів виробництва продукції. Ця концепція зводить процес інтенсифікації лише до одного елемента виробництва - праці, виключаючи, що зростання випуску продукції може відбуватися й завдяки екстенсивному розвитку. Прибічники «результативної» концепції основу сутності інтенсифікації грунтують на результативних показниках процесу виробництва. Проте таке визначення не відображає причинно-результативного зв’язку економічного процесу інтенсифікації. Взявши за основу лише результат 
виробництва, прихильники цієї концепції недооцінювали роль витрат i капітальних вкладень у розвиток виробництва. Не можна збільшити обсяг виробництва продукції при незмінних витратах на ії одиницю, не залучивши додаткових ресурсів.

Багато вчених ототожнюють процеси інтенсифікації з науково-технічним прогресом, розглядаючи інтенсифікацію виробництва лише з позиції зростання технічного рівня виробництва. Особливо багато праць 3 цього питання публікувалися у 60-ті - 90-ті роки минулого століття, про що свідчить детальний аналіз таких публікацій [8,9]. Ми підтримуємо думку авторів про те, що така концепція $є$ неповною, однобічною. У цьому контексті вірно зазначати, що науково-технічний прогрес $\epsilon$ вирішальним чинником інтенсифікації виробництва і економічного зростання, який припускає розвиток фундаментальних досліджень, прикладних досліджень, розробку i впровадження нових технологій, створення принципово нової техніки та обладнання. Цей процес в цілому носить назву інноваційного. На думку вчених, доцільно ввести поняття «інноваційна інтенсифікація виробництва».

Сучасні трактування сутності інтенсифікації виробництва в переважній більшості базуються, в основному, на тезі про те, що інтенсифікація виробництва в цілому $є$ комплексним процесом, що включає такі складові частини як заходи науково-технічного прогресу, концентрації, спеціалізації, вдосконалення управління тощо [8-12].

Так, М.С. Вітков визначає інтенсифікацію виробництва як комплексний, багатофакторний процес застосування ефективних і екологічно безпечних засобів та технологій, заснованих на досягненнях науково-технічного прогресу, інноваційних розробках, використанні більш досконалих форм організації і оплати праці, управління та ефективних ринкових відносин [10].

Близькою за змістом є думка авторів [8], які розглядають інтенсифікацію виробництва як процес застосування ефективніших засобів виробництва i технологічних процесів з урахуванням досягнень науково-технічного прогресу, застосування досконалішої організації праці та управління 3 метою забезпечення безперервного приросту виробництва i підвищення його ефективності.

3 точки зору С.В. Степаненка інтенсифікація виробництва - процес більш повного використання його факторів, їхнє якісне удосконалення, а також поліпшення технологій використання продуктивних можливостей цих факторів та відповідне зменшення ролі простого кількісного нарощування факторів, не пов'язаних з суттєвим поліпшенням їхнього застосування[11].

Досить змістовним, на нашу думку, є твердження Н.А. Агарковоїпро те, що інтенсифікувати виробництво - означає зробити більш напруженим i посиленим як процес виробництва в цілому, так і окремі його складові[9].

Таким чином, досліджені наукові уявлення про сутність інтенсифікації виробництва, на наш погляд, можна систематизувати наступним чином (рис. 1): - визначення сутності інтенсифікації виробництва з позиції теорії відтворення (основний зміст - розширене відтворення); 
- визначення сутності інтенсифікації виробництва 3 позиції «затратного» підходу (основний зміст - концентрація капіталу з метою нарощення обсягів виробництва продукціі);

- визначення сутності інтенсифікації виробництва 3 позиції «результативного» підходу (основний зміст - збільшення обсягів виробництва продукції при незмінних витратах);

- визначення сутності інтенсифікації виробництва 3 позиції «технічного» підходу (основний зміст - зростання технічного рівня виробництва завдяки науково-технічному прогресу);

- визначення сутності інтенсифікації виробництва 3 позиції «комплексного» підходу (основний зміст - застосування більш ефективніших засобів виробництва, технологій, форм організації праці та управління).

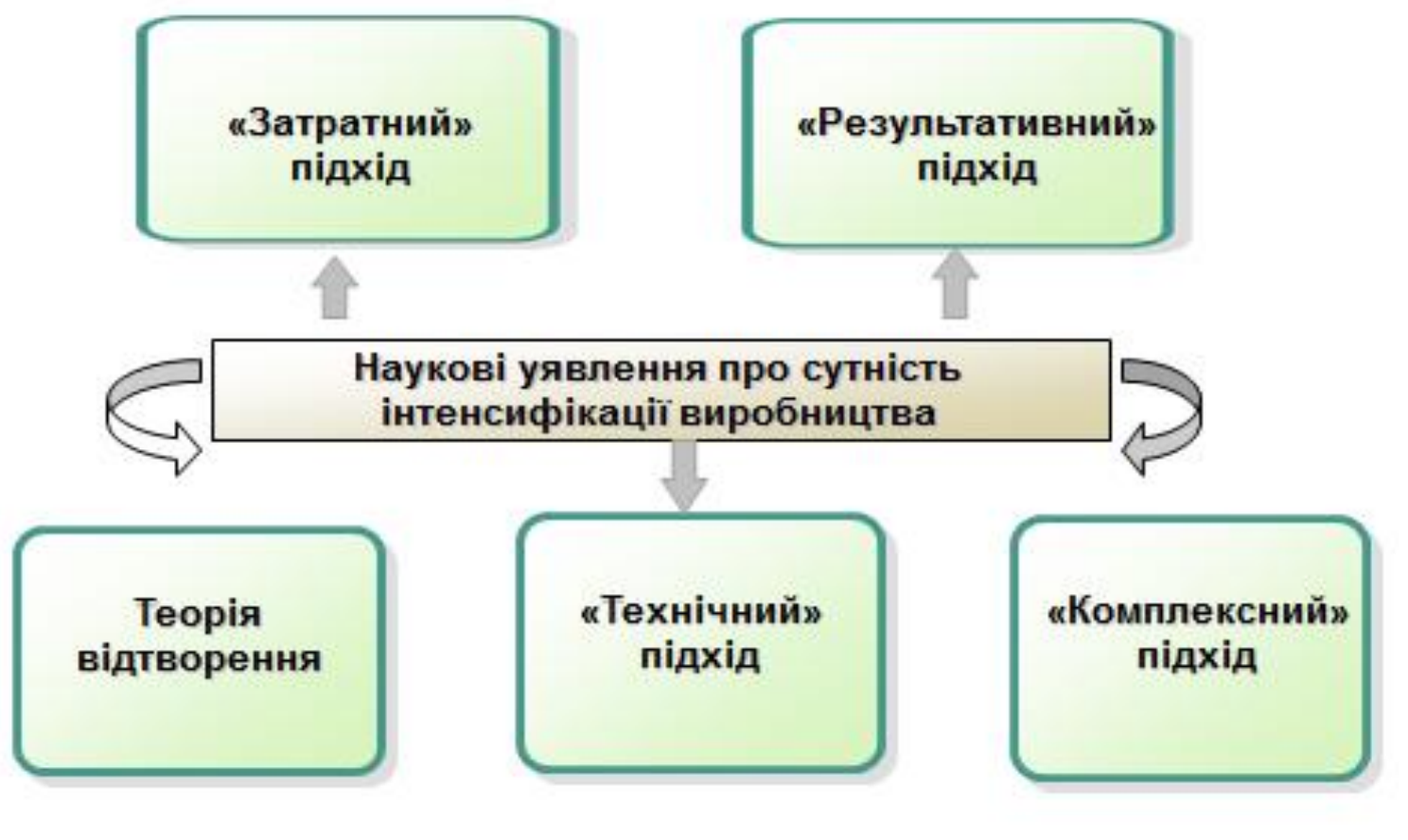

Рис. 1. Систематизація наукових уявлень про сутність інтенсифікації виробництва (розроблено на основі аналізу [7-12])

Отже, за результатами аналізу вищенаведенихнауково-практичних джерел можна стверджувати, що теорія інтенсифікації виробництва ще не склалася, вона не сформована остаточно, не є сталою і розвивається.

При цьому, на мою думку, існуючі наукові погляди про визначення сутності інтенсифікації виробництва об'єднує те, що відправною точкою розгляду у кожного з них $\epsilon$ розгляд виробництва як процесу, або як системи, або як процесу і системи одночасно.

Таким чином, підсумовуючи наукові розробки та думки вчених, на наш погляд, інтенсифікації виробництва можна дати коротке та розгорнуте визначення. Коротке визначення інтенсифікаиії виробництва можна 
сформулювати наступним чином: інтенсифікація виробництва - це системний процес застосування найбільш ефективних чинників 3 метою забезпечення безперервного приросту виробництва й підвищення його ефективності. Розширене визначення сутності ідентифікації полягає в наступному: інтенсифікація виробництва - це системний комплексний багатофакторний процес застосування ефективніших засобів виробництва i технологічних процесів з урахуванням досягнень науково-технічного прогресу та інноваційних розробок, застосування досконалішої організації праці та управління 3 метою забезпечення безперервного приросту виробництва i підвищення його ефективності.

Складні соціально-економічні перетворення, що відбуваються на сучасному етапі суспільно-економічних трансформацій в Україні, потребують запровадження дієвих механізмів економічного зростання. Беручи за мету соціально-економічнийрозвиток України підвищення якості життя населення, формування сприятливого середовища існування, збереження соціальнополітичної стабільності і забезпечення національної безпеки й обороноздатності, регулювання економіки має відбуватися, насамперед, в напрямі інтенсивного шляху розвитку промислового комплексу.

Вочевидь, що інтенсифікація промислового виробництва на макроекономічному рівні $є$ елементом більш складного системного процесу інтенсифікації вітчизняного народногосподарського комплексу.

У свою чергу інтенсифікація промислового виробництва на мікроекономічному рівні $\epsilon$ також системним процесом, складовими якого $\epsilon$ процеси інтенсифікації функціональних модулів виробництва як системи.

Висновки. Наукова новизна проведеного дослідження полягає в уточненні сутності поняття «інтенсифікація виробництва» за результатами його аналізу 3 позицій теорії відтворення, «затратного», «результативного», «технічного» та «комплексного» підходів.

Запропоновані коротке та розгорнуте визначення інтенсифікації виробництва як системного процесу можна розглядати як елементи узагальнення теоретико-методологічних аспектів економічної сутності інтенсифікації виробництва.

Подальші наукові дослідження інтенсифікації промислового виробництва повинні орієнтуватися на виділення, проведення змістовного вивчення та здійснення грунтовного аналізу ключових чинників та напрямів інтенсифікації промислового виробництва.

\section{Література:}

1. Перший етап модернізації економіки України: досвід та проблеми: [монографія] / [O.М. Алимов, О.І. Амошата ін.] ; за заг. ред. В.І. Ляшенка; ІЕП НАН України, КПУ. Запоріжжя : КПУ, 2014. - 798 с.

2. Маркс К. Твори. Т.25. Ч.ІІ / К. Маркс, Ф. Енгельс. - 2-ге вид. -Видавництво політичної літератури України, 1962. - 511 с.

3. Маркс К. Твори. Т.24 / К. Маркс, Ф. Енгельс. - 2-ге вид. - Видавництво політичної літератури України, 1962. - 645 с.

4. Борисов А. Б. Большойэкономическийсловарь / А. Б. Борисов. - М. : Книжный мир, 2003. -895 c. 
5. Райзберг Б.А. Современныйэкономическийсловарь / Б.А. Райзберг, Л.Ш. Лозовский, Е.Б. Стародубцева. - 2-е изд., испр. - М.: ИНФРА-М., 1999. - 479 c.

6. Економічна енциклопедія: у 3-х томах. Т. 1. / [відп.ред. С.В. Мочерний]. - К.: Видавничий центр «Академія», 2000. - 864 с.

7. Важинський Ф.А. Техніко-технологічне оновлення як фактор інтенсифікації виробництва [Електронний ресурс] / Ф.А. Важинський, Л.С. Ноджак, Ю.Б. Шульган. Режим доступу :

http://dspace.nbuv.gov.ua/bitstream/handle/123456789/2577/st_36_05.pdf?.

8. Горбачов В.С. Еволюція і сучасний стан наукових уявлень про і інтенсифікацію виробництва / В.С. Горбачов, О.П. Гурченков // Економіка України. - 2005. - №1 . - С.53-59.

9. Агаркова Н.А. Теоретико-прикладні аспекти інтенсифікації виробництва [Електронний ресурс] / Н.А. Агаркова // Вісник Хмельницького національного університету. - 2009. - № 6. - ․2. - С. 186-190.- Режим доступу: http://journals.khnu.km.ua/vestnik/pdf/ekon/2009_6_2/186-190.pdf.

10. Вітков М.С. Основні фактори інтенсифікації аграрного виробництва в перехідний період до ринку / М.С. Вітков // Економіка АПК. - 2005. - № 2. - С. 17-20.

11. Степаненко С. В. Основи економічної теорії: політекономічний аспект: [навчальний посібник] / С.В. Степаненко. - К.: КНУ ім. Т. Шевченка, 2004. - 350 с.

12. Яровенко Т.С. Управління процесом інтенсифікації розвитку промислового підприємства у сучасних умовах [Електронний ресурс] / Т. С. Яровенко, М. В. Тулякова, Ю. А. Козюпа // Вісник Дніпропетровського університету. Серія «Економіка». Вип. 7(2). - 2013. - №4. - $\quad$ T.21. - C.105-110. - Режим доступу: http://vestnikdnu.com.ua/archive/201372/yarovenko.html. 